\title{
Increasing Productivity of Malabar Spinach (Basella alba L. and Basella rubra L.) Grown in the Marginal Upland Area of Inopacan, Leyte Through Different Mulching Materials
}

\author{
Zenaida C. Gonzaga', Hubert B. Dimabuyu', \\ Richielda R. Sumalinog ${ }^{1}$ and Othello B. Capuno ${ }^{2}$ \\ ${ }^{1}$ Department of Horticulture Visayas State University, ${ }^{2}$ Office of the Vice President \\ for Research and Extension, Visayas State University, Visca, Baybay City, Leyte \\ 6521-A
}

\begin{abstract}
Basella or malabar spinach, locally known as alugbati is a tropical leafy indigenous vegetable commonly grown for its succulent, nutritious, and tender stems. It has also a number of medicinal applications. Despite its many uses and potential value, its importance is under estimated. The study was conducted to evaluate the effects of different mulching materials on the growth and yield of two Basella species grown in a rolling soil in the marginal uplands of in Inopacan, Leyte. A factorial experiment was set-up with Alugbati species/varieties as the main plot factor and the different mulching materials as the sub-plot. Treatments were: T0- control, T1- rice hull, T2-rice straw and T3- plastic mulch.

Basella alba, the green-stemed alugbati had significantly bigger stems, greater number and heavier shoots than the red-stemed Basella rubra. Leaf spot disease caused by Colletotrichum sp. was more evident in B. rubra. Regardless of the mulching materials used, mulched plants yielded higher than the unmulched plants or those planted in bare soil. Moreover, the use of silver plastic mulch resulted to the highest total yield. The results indicate the high potential of mulching in increasing the yield and thus the profitability of alugbati production.
\end{abstract}

Keywords: Alugbati, Basella alba, Basella rubra, plastic mulch, rice hull, rice straw

Correspondence : Z.C. Gonzaga Address: Department of Horticulture, Visayas State University, Visca Baybay City, Leyte 6521-A Email: zcgonzaga@yahoo.com

DOI: 10.32945/atr36s11.2014 


\section{INTRODUCTION}

Malabar spinach or ceylon spinach, commonly known as alugbati is a vegetable which belongs to Basellaceae family. It is a fast growing vegetable, native to tropical Asia (India or Indonesia) and extremely heat tolerant. It is commonly grown for its young shoots which make an excellent succulent, slightly mucilaginous vegetable. It is high in Vitamins A, B9 and C, iron and calcium (Grubben and Denton, 2004).

Alugbati is a very productive leafy vegetable, suitable for both home and market garden in the lowland tropics (Siemonsma and Piluek, 1994). Its thick, semi-succulent, heart-shaped leaves have a mild flavour and mucilaginous texture. Daily consumption of malabar spinach has been shown to provide vitamin A especially in populations that are at high risk of vitamin A deficiency (Haskell et al., 2004). A number of medicinal applications have been reported: young leaves as laxative, pulped leaves to poultice sores, red fruit juice as eye-drops to treat conjunctivitis. The red forms are likewise planted as ornamental. A need to increase its production is seen as a potential means of solving nutrition problem in a cheaper way as alugbati is very easy to grow without much inputs.

One cultural management practice employed to increase yield of vegetable is mulching. Mulches are natural (straw, sawdust, herbage and other materials) or synthetic (polyethylene in different colors) materials placed on the soil surface. These are well known for modifying the energy and water balance at the surface of soils creating more favorable conditions for plant growth. Direct effects include increased in soil temperature (Farias-Larioset et. al., 1994), decrease in moisture loss from the soil, prevention of weed development (Borosic, et al., 1998), control of soilborne pathogens, and reduced insect/pest populations (Farias-Larios and Orozco-Santos, 1997). Mulching is considered as an agrotechnical procedure which can significantly modify microclimate around plants (Siwek et al., 2007). Application of mulches beneficially influences soil structure, reduces negative effects of wind and water erosion, and decreases soil warming in summer months (Holderbaum et al., 1990) Favorable microclimatic conditions created by mulching can ensure, among other things, higher yields, products of better quality or/and earliness, as well as a more cost-effective production. The use of mulches is known to be worthwhile being an important reason for the crop's quality and productivity improvement (Fontanettiverdial et al., 2001). 
Increasing Productivity of Malabar Spinach Grown In The Marginal Uplands

Despite the potential value of alugbati, it received lesser attention which means it is under-estimated and under-exploited; hence no production data are available. Through the Philippine Higher Education Research Network (PHERNet) project, an attempt to increase production of alugbati has been conducted. Its importance to Filipino diets, the medicinal application and the interest of increasing its yield through improved cultural management practices constitute a challenge to researchers to come up with a technology to provide the crop with a favorable environment so as to increase its production. In view of the foregoing considerations, conducting research work on the use of mulching on alugbati production was deemed necessary. Specifically, the study was conducted to evaluate the influence of different mulching materials on the growth and yield of two alugbati species/varieties and to do a cost and return analysis of mulched and unmulched alugbati production.

\section{MATERIALS AND METHODS}

\section{Soil Sampling and Land Preparation}

This study was conducted in Sitio Batuan, Barangay Linao, Inopacan Leyte. The soil used is clay loam having a $5.0 \mathrm{pH}, 2.55 \% \mathrm{OC}, 0.26 \%$ total N, $2.94 \mathrm{mg} / \mathrm{kg}^{-1} \mathrm{P}$ and $153.78 \mathrm{mg} / \mathrm{kg}^{-1} \mathrm{~K}$. An area of $186 \mathrm{~m}^{2}$ was plowed and harrowed two times to pulverize the soil and remove weeds. Beds measuring $0.8 \mathrm{~m} \times 6.0 \mathrm{~m}$ were then constructed.

\section{Preparation of Alugbati transplants}

Fresh terminal shoots of alugbati were procured from the local market of Baybay City. These were trimmed to a uniform length of $20 \mathrm{~cm}$ and planted in polyethylene pots with a mixture of 2:1:1 garden soil, carbonized rice hull and aged chicken dung. Cuttings were then planted into pots measuring $7.5 \mathrm{~cm} \mathrm{x} 10 \mathrm{~cm}$ with $7.5 \mathrm{~cm}$ portion of the stem buried into the medium and allowed to form roots.

\section{Experimental Design and Treatments}

The experimental area was laid out using Split-plot Design arranged in RCBD with three replications. Each treatment plot measured 0.8 
$\mathrm{m} \times 6.0 \mathrm{~m}$. One row of plants was established in each plot with spacing of $0.5 \mathrm{~m}$ per hill and $0.5 \mathrm{~m}$ per rows. An alleyway of $0.5 \mathrm{~m}$ was provided between replications to facilitate farm operation and management as well as data gathering. The treatments were as follows:

Factor A:Alugbati species/varieties

$\mathrm{V}_{1}$ - Red Alugbati (Basella rubra Linn.)

$\mathrm{V}_{2}$ - Green Alugbati (Basella alba Linn.)

Factor B: Different mulches

T0 - control (no mulch)

T1 - Rice straw

T2 - Rice hull

T3 - Silver Plastic

\section{Cultural Management}

Rooted alugbati cuttings were transplanted unto plots measuring 6.0 $\mathrm{m}$ at $0.80 \mathrm{~m}$ at $0.5 \mathrm{~m}$ distance between hills. Five hundred grams of rice hull charcoal and $10 \mathrm{~g}$ complete (14-14-14) fertilizers were applied upon transplanting in each hill. Two weeks after planting, $150 \mathrm{ml}$ of 75 grams urea dissolved in 16 liter of water was drenched.

Two (2) centimeter thick of rice straw and rice hull were spread over the designated treatment plots right after planting. The plastic mulch on the other hand, was spread ahead of planting. Right after spreading the plastic mulch, it was fastened by clipping the sides with bamboo sticks formed like a staple wire. Holes about $10 \mathrm{~cm}$ diameter were made on the plastic using can containing burned charcoal, then transplanting of Basella was done.

Trellising was done one week after transplanting using $1.5 \mathrm{~m}$ long slated bamboos tied with plastic twines. Pests were controlled by pruning or removal of infected and infested shoots.

Harvesting was done weekly by cutting the terminal shoots which were then classified as marketable and non-marketable. Marketable shoots are free from diseases and insect damage while non-marketable shoots are diseased and damaged. Number and weight of each were then recorded. 
Increasing Productivity of Malabar Spinach Grown In The Marginal Uplands

\section{Data Gathered}

A. Horticultural Characteristics

1. Stem Diameter $(\mathrm{cm})$ - This was obtained by measuring the diameter of the shoots one (1) $\mathrm{cm}$ from the cut portion of the cuttings at harvest which was $38 \mathrm{~cm}$ from the tip.

2. Number of marketable and non-marketable terminal shoots per plot - This was determined by counting the number of marketable and nonmarketable cuttings from each sample plants after sorting.

3. Weight of marketable and non-marketable terminal shoots ( $\mathrm{kg} / \mathrm{plot}$ )

- This was determined by weighing the marketable and nonmarketable shoots after sorting in each harvest.

4. Total yield (tons/ha). - This was determined by getting the cumulative weight of the cuttings from the first to the last harvest.

B. Meteorological Data

Data on total weekly rainfall and average weekly soil temperature and moisture from each plot were gathered.

Statistical Analysis

The data obtained were analysed using Cropstat 7.2 and the means were compared using Duncan Multiple Range Test at 5\% level of probability.

Cost and Return Analysis

This was determined by taking into account all the cost of production from land preparation to harvest and the income obtained. Gross income was calculated by determining the number of bunches generated from the total shoots harvested. Number of shoots per bunch was based on the one sold in the market which is 10 shoots on the average, the price of which is P5.00 per bunch. Net income was calculated by subtracting the production cost from gross income. 


\section{RESULTS AND DISCUSSION}

\section{Horticultural Characteristics}

The two Basella species differed in their horticultural characteristics (Table 1). Green alugbati had bigger stems than the red alugbati. Number of marketable shoots and total yield were likewise significantly higher in the green stemmed alugbati. Results could be due to genetic differences of the two species. In terms of the effect of the different mulching materials showed that regardless of its kind, whether organic i.e. rice hull and rice straw or inorganic, the silver plastic mulch enhanced the production of greater number and heavier marketable shoots. Furthermore, in terms of total yield, plastic mulched Basella yielded the highest. The findings of Khazaei et al, (2013) also pointed out that mulching significantly increased the total yield of lettuce using silver plastic films.

The better performance of mulched plants over that of unmulched (Fig. 1) can also be ascribed to its contribution to weed management via reducing weed seed germination, blocking weed growth, repelling insect and favouring the crop by conserving soil moisture (Fig. 2) at the same time moderating soil temperature (Fig. 3). This is in consonance with the result of the study of Jenni et al. (2004) showed that polyethylene with at least one black side was effective in controlling weed growth, and that growing lettuce on polyethylene mulches increased marketable yield by $7 \%$ and resulted in significantly heavier heads of lettuce compared to those of the control. Zhang et al. (2005) also observed that mulching with straw reduced soil evaporation loss and increased water use efficiency of winter

wheat in northern China. In addition, organic mulch, once decomposed adds organic matter to the soil. (Schonbeck, 2012). The better development of plants in the treatment with double-faced plastic covering could be explained by the higher light reflection caused by the silver side of this kind of mulch, which could have increased the accumulation of photosynthates by the leaves (Muller, 1991). This might have influenced the higher nitrogen absorption by the plants. The results obtained are in accordance with Walker, quoted by Muller (1991). According to the author, higher soil temperature, which was also observed in this study (Fig. 3) lead to higher absorption of nitrogen and greater vegetative growth. Pinto (1997) mentioned the loss of nitrogen in the soil profile by leaching of nitrate in bare soils. Furthermore, there was a decrease in the oxygen concentration in the rhizosphere for treatments of no mulch, 
Increasing Productivity of Malabar Spinach Grown In The Marginal Uplands

which promoted better aeration. Thus, the nitrate is used by microorganisms as an alternative electron receptor, increasing the risk of nitrogen loss by denitrification or partial nitrification of the ammoniacal nitrogen (Marschner, 1995).

\section{Disease Incidence}

Leaf spot disease caused by Colletotrichum sp. was more evident in $B$. rubra than in B. alba regardless of the mulching materials used (Fig. 4 and $5)$. The higher disease incidence could be due to the occurrence of the heavy rainfall throughout the experimental period (Fig. 6). It was noted that B. rubra is susceptible to the disease while B. alba is resistant. However with continuous rain, disease infection become unmanageable with the use of physical means in controlling the disease infection.

Table 1. Horticultural characteristics of two Basella species grown under different mulching materials

\begin{tabular}{|c|c|c|c|c|c|c|}
\hline & \multirow{3}{*}{$\begin{array}{c}\text { Stem } \\
\text { Diameter }\end{array}$} & \multicolumn{4}{|c|}{ Plot yield $/ 4.8 \mathrm{~m}^{2}$} & \multirow{3}{*}{$\begin{array}{l}\text { Yield } \\
(\mathrm{t} / \mathrm{ha})\end{array}$} \\
\hline & & \multicolumn{2}{|r|}{ Number } & \multicolumn{2}{|c|}{ Weight (kg) } & \\
\hline & & Marketable & Non-marketable & Marketable & Non-marketable & \\
\hline \multicolumn{7}{|l|}{ Variety } \\
\hline $\begin{array}{l}\text { Red }(B . \\
\text { rubra) }\end{array}$ & $0.63 b$ & $302.37 b$ & 39.94 & 4.27 & 0.46 & $9.29 \mathrm{~b}$ \\
\hline $\begin{array}{l}\text { Green }(B . \\
\text { alba) }\end{array}$ & $0.72 \mathrm{a}$ & $394.05 \mathrm{a}$ & 43.42 & 4.35 & 0.34 & $9.82 \mathrm{a}$ \\
\hline \multicolumn{7}{|l|}{ Treatments } \\
\hline T0-Control & 0.66 & $313.51 \mathrm{~b}$ & 40.49 & $3.77 \mathrm{~b}$ & 0.38 & $8.38 \mathrm{~b}$ \\
\hline $\begin{array}{l}\text { T1-Rice } \\
\text { hull }\end{array}$ & 0.66 & $337.40 \mathrm{a}$ & 44.66 & $4.23 \mathrm{a}$ & 0.41 & $9.39 \mathrm{~b}$ \\
\hline $\begin{array}{l}\text { T2-Rices } \\
\text { traw }\end{array}$ & 0.68 & $361.21 \mathrm{a}$ & 39.40 & $4.43 \mathrm{a}$ & 0.38 & $9.44 \mathrm{~b}$ \\
\hline $\begin{array}{l}\text { T3- Silver } \\
\text { Plastic }\end{array}$ & 0.71 & $380.72 \mathrm{a}$ & 42.16 & $4.81 \mathrm{a}$ & 0.42 & $\begin{array}{c}11.02 \\
\mathrm{a}\end{array}$ \\
\hline $\mathrm{CV}$ a $(\%)$ & 0.07 & 0.04 & 0.49 & 0.16 & 0.67 & 0.16 \\
\hline $\mathrm{CV} \mathrm{b}(\%)$ & 0.54 & 0.05 & 0.23 & 0.03 & 1.03 & 0.04 \\
\hline
\end{tabular}

Means within the same column having the same letter or without letter designation are not significantly different at 5\% level of significance using Duncan's Multiple Range Test. 

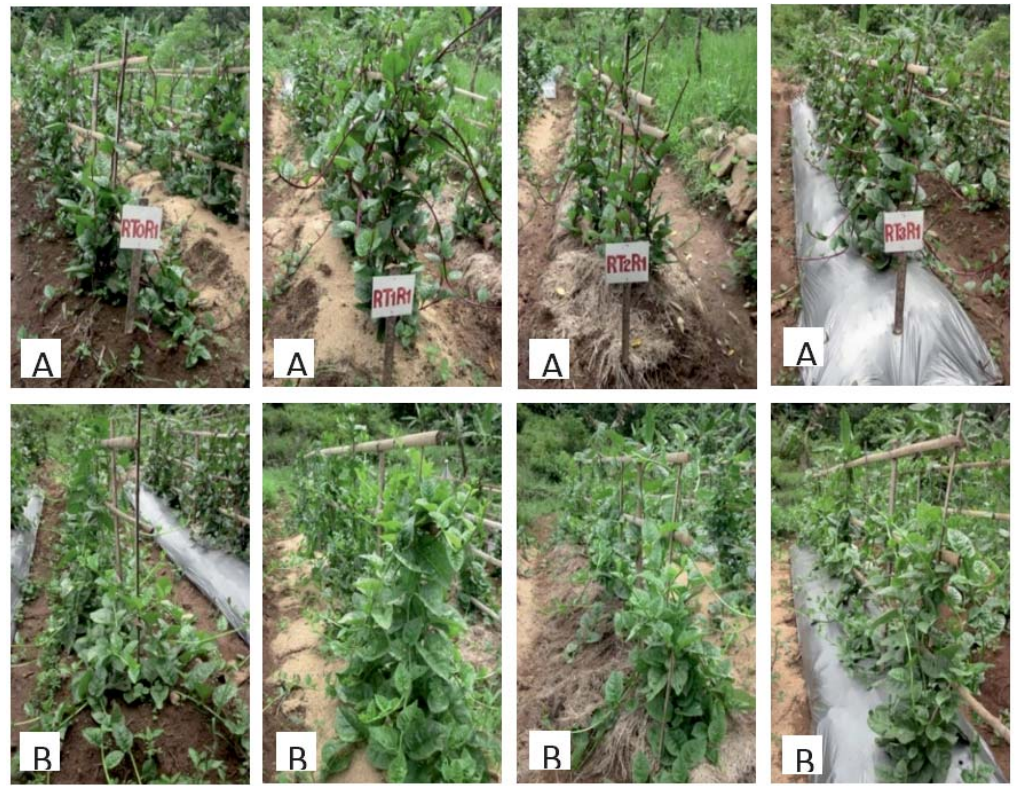

Figure 1. Basella rubra (A) and Basella alba (B) planted without mulch (1), rice hull (2), rice straw (3) and plastic (4).

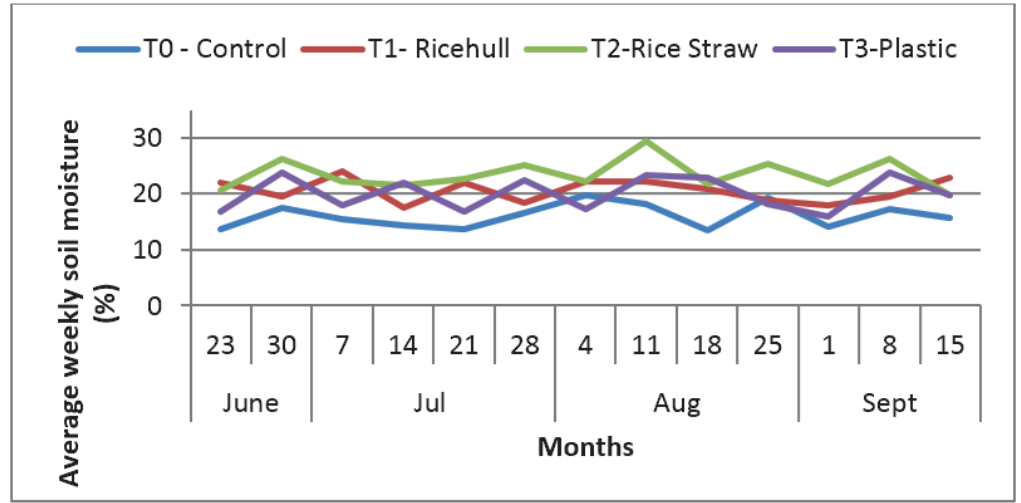

Figure 2. Average weekly soil moisture during the conduct of the study (June-Sept., 2013). 


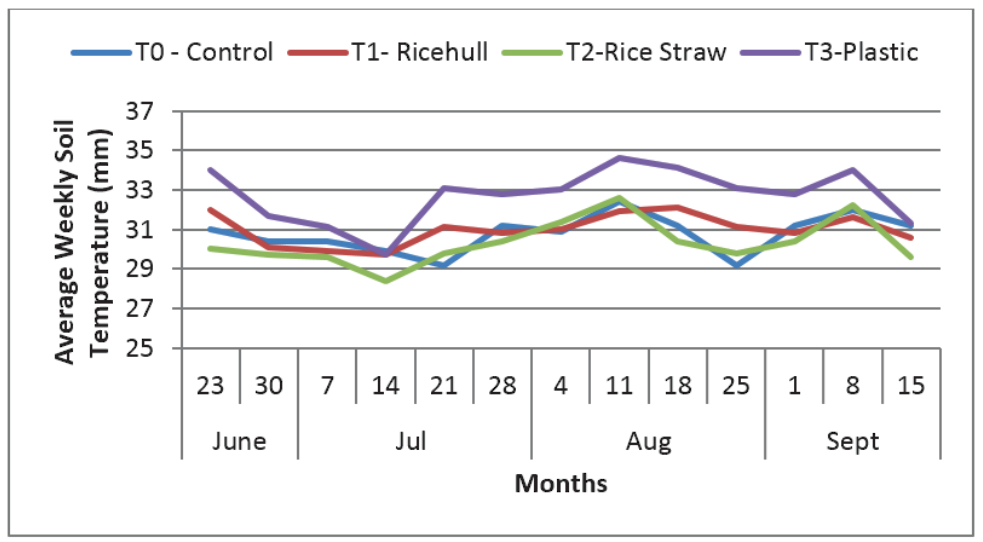

Figure 3. Average weekly soil temperature during the conduct of the study (June-Sept., 2013).

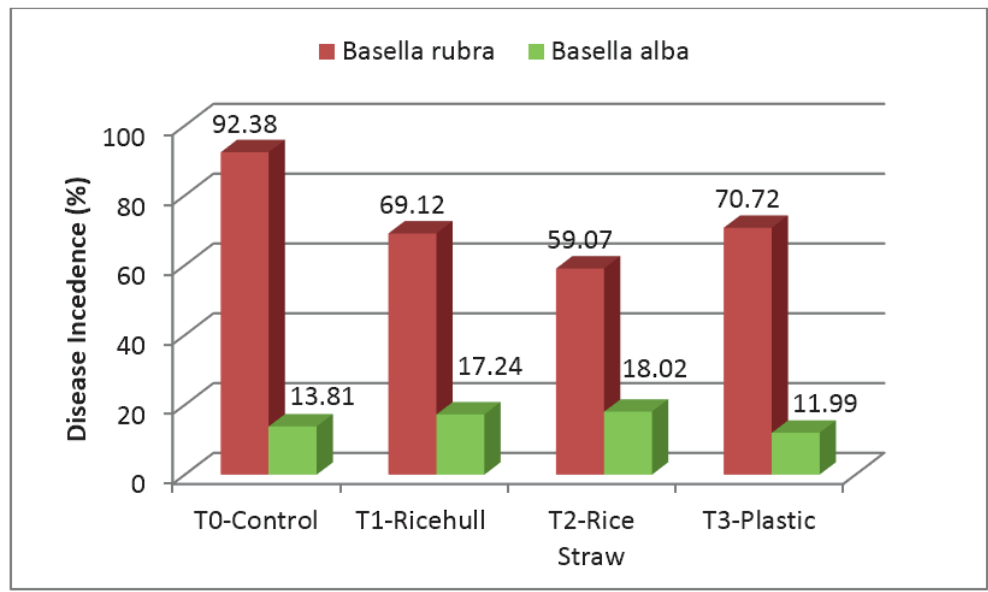

Figure 4. Percent disease incidence (Colletotrichum sp.) three and one half months from planting.
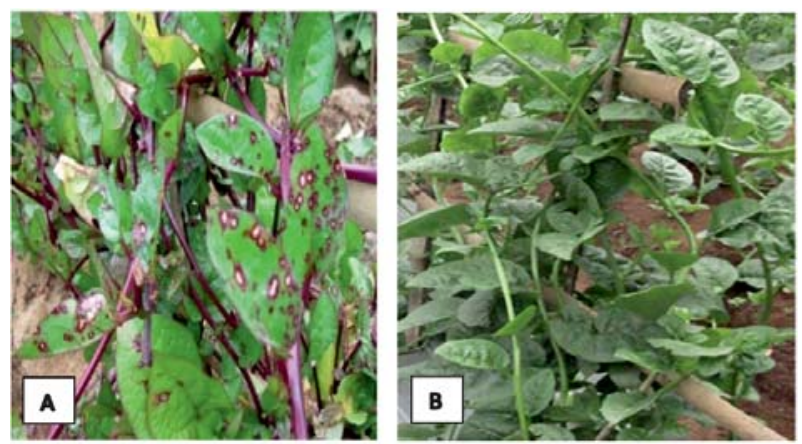

Figure 5. (A) Basella rubra infected by Colletotrichum sp., (B) Basella alba showing resistance to infection. 


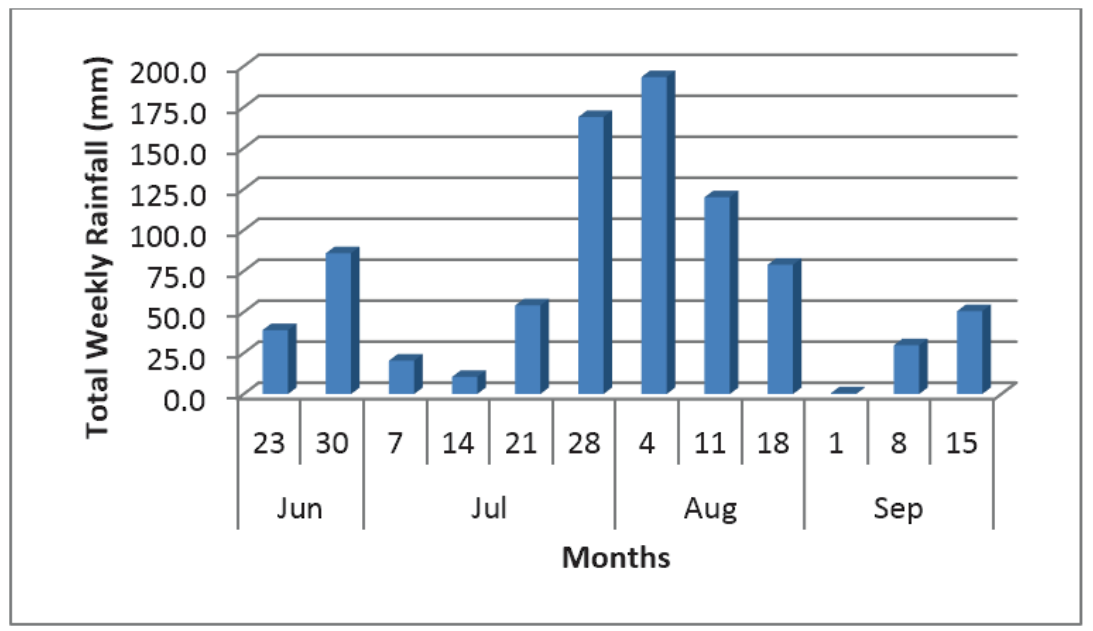

Figure 6. Total weekly rainfall (mm) during the conduct of the study (June-Sept., 2013)

Estimates on the cost and return of alugbati production

Cost and return analysis of B. rubra and B. alba grown with different mulching materials are presented in Table 2 . It was noted that production of $B$. alba gave a higher net return. Production of Basella without mulch incurred the highest total production cost of Php 3,018.25, followed by plastic mulch. The use of the two organic mulches had the same expenditures.

All the three mulching materials had higher net returns than the control or unmulched plants. This was due to the higher number of bunches produced in mulched plants. The plastic mulch, however, yielded the highest profit of $\mathrm{PhP}$ 1,587.05, followed by rice straw of $\mathrm{PhP} 1,470.45$ and rice hull of PhP 1,399.80.

\section{CONCLUSIONS}

Based on the results obtained, the following conclusions were drawn:

1. Mulching with the use of straw, rice hull and plastic mulch enhanced growth and yield of Basella. Furthermore, these mulching materials had superior effect over that of unmulched treatment or bare soil in terms of number and weight of marketable shoots.

2. Plants mulched with silver plastic produced the highest yield and consequently gave the highest net returns. 
Increasing Productivity of Malabar Spinach Grown In The Marginal Uplands

Table 2. Estimates on the cost and return of alugbati production as affected by mulching per 182 $\mathrm{m}^{2}$.

\begin{tabular}{lcccc}
\hline Treatments & $\begin{array}{c}\text { Number of } \\
\text { bunches* }\end{array}$ & $\begin{array}{c}\text { Gross } \\
\text { Income** }\end{array}$ & $\begin{array}{c}\text { Total Expenses } \\
(\mathrm{PhP})\end{array}$ & $\begin{array}{c}\text { Net } \\
\text { Income** }\end{array}$ \\
\hline Variety & & & & \\
Red $($ B. rubra $)$ & 725.69 & $3,628.45$ & $2,981.45$ & 647.00 \\
Green $($ B. alba) & 945.7 & $4,728.50$ & $2,981.45$ & $1,747.05$ \\
Treatments & & & & \\
T0-Control & 752.42 & $3,762.10$ & $3,018.25$ & 743.85 \\
T1-Rice hull & 795.61 & $3,978.05$ & 2578.25 & $1,399.80$ \\
T2-Rice straw & 809.74 & $4,048.70$ & 2578.25 & $1,470.45$ \\
T3-Plastic & 913.70 & $4,568.50$ & 2981.45 & $1,587.05$ \\
\hline
\end{tabular}

* Number of bunches were computed by considering the average number of shoots per bunch in the market

** Obtained by multiplying the number of bunches with the current price of Basella at 5 $\mathrm{PhP} /$ bunch

\section{RECOMMENDATIONS}

1. Under the condition of the study where rainfall was abundant, mulching using plastic mulch is recommended.

2. Similar study should be conducted during one season to determine any differences in the response of Basella to the different mulching materials.

\section{REFERENCES}

BOROSIC, J., D. ROMIC, F. TOMIC, I. ZUTIC and Z. KLACIC. 1998: Effects of mulching and irrigation in bell pepper (Capsicum annuum L.) growing in Mediterranean part of Croatia. Agriculturae Conspectus Scientificus 63, 325-330.

FARIAS-LARIOS, J. and M. OROZCO-SANTOS. 1997. Effect of polyethylene mulch color on aphid populations, soil temperature, fruit quality and yield of watermelon under tropical conditions. New Zealand Journal of Crop and Horticultural Science, 25: 369-374.

FONTANETTIVERDIAL M, M SANTOS DE LIMA, AF MORGOR and R GOTO. 2001. Production of iceberg lettuce using mulches. Scientia Agricola, v.58, n.4, p.737-740. 
GRUBBEN, G.J.H. and DENTON, O.A. 2004. Plant Resources of Tropical Africa 2. Vegetable. PROTA Foundation, Wageningen; Backhuys, Leiden; CTA, Wageningen. 4: 103-111.

HASKELL, M. J., JAMIL, K.M., HASSAN, F., PEERSON, J.M., HASSAIN, M.I., FUCHS, G.J. and BROWN, K.H. 2004. Daily consumption of Indian spinach $(B . a l b a)$ or sweet potato has positive effect on total-body vitamin A store in Bangladeshi men. Am. J. Clin. Nutr. 80(3): 705-714

HOLDERBAUM J.F., DECKER A.M., MEISINGER J.J., MULFORED F.R. and L.R., VOUGH 1990. Fall-seeded legume cover crops for no tillage corn in the humid East. Agron. J., 82(1), 117-124.

JENNI S, BRAULT D and KA STEWART. 2004. Degradable mulch as an alternative for weed control in lettuce produced on organic soils. Acta Hort. 638, 111-118.

KHAZAEI I, R SALEHI, A KASHI and SM MIRJALILI. 2013. Improvement of lettuce growth and yield with spacing, mulching and organic fertilizer. IntlJAgri Crop Sci. Vol., 6 (16), 1137-1143,

MARSCHNER, H. 1995. Mineral nutrition of higher plants. New York: Academic Press,. 674p.

MULLER, A. G. 1991. Thermal behavior of the soil and air in lettuce (Lactuca sativa L.) for different types of coverage of solo Piracicaba , Thesis (Masters) - Escola Superior de Agricultura "Luiz de Queiroz", University of Sao Paulo. 77p.

PINTO, J. P. 1997. Effect of types of covers of black polyethylene in evapotranspiration and the production of lettuce. Lush, Thesis (M.S.) Federal University of Vicosa. 55p.

SCHONBECK, M. 2012. Mulching for weed management in organic vegetable production. Virginia association for biological farming. (Available online at: www.extension.org/pages/62033/mulching-forweed-management-in-organic-vegetable-production.) 
Increasing Productivity of Malabar Spinach Grown In The Marginal Uplands

SIEMONSMA, J.S. and K. PILUEK.1994. Plant Resources of South-East Asia: Vegetables. Prosea. Bogor. Indonesia. vol. 8.

SIWEK P, KALISZ A and R. WOJCIECHOWSKA. 2007. Effect of mulching with film of different colours made from original and recycled polyethylene on the yield of butterhead lettuce and celery. Foloia Horticulturae. 19/1,25-35.

ZHANG X, S CHEN, M PEI LIU and H SUN. 2005. Improved water use efficiency associated with cultivars and agronomic management in the north China plain. Agron J. 97:783-790. 